\title{
Digital appendix 2. Newly discovered Australian works and authors
}

The table below includes authors identified as Australian in existing reference sources (e.g. AustLit; Australian Dictionary of Biography) or where there is strong evidence the author is Australian in the publication event and/or elsewhere in the digitized newspaper record. It focuses on authors with a significant presence relating either to the number or length of their works and excludes newly identified versions of stories already in the bibliographical record, regular newspaper columns of a fictional nature, authors identified by their initials only, and multiple short stories (completed in one or two newspaper issues). Among the short fiction excluded from the table below are numerous titles by the below authors and others including Winifred Crabbe, W. G. Henderson, Chas. R. Hodge, George Isaacs, Ethel Mills, Frank Morley, Sidney Partridge, T. H. Prichard, Adelaide Primrose, Alice Grant Rosman, Racey Schlank, Mrs C. E. Tibbs, G. Walstab, and Frederick Sydney Wilson. These titles and their full publication details are available in the curated dataset, as are those for the titles listed below and for newly discovered extended fiction by Australian authors published in early twentieth-century Australian newspapers, including E. J. Bowling, John X.

Cameron, F. D’A. C. De L'Isle, Edwin Doidge, W. T. Goodge, Isabel Grant, Oliver

H. Growden, Gifford Hall, Foster Osborne, A. Nugent Robertson, Jean C. Robinson, Jack Rugby, Charles C. Russell, John Sandes, Edward S. Sorenson, Edward A.

Vidler, Marjorie Weatherly, Kate Helen Weston, Walter D. White, and Adeline J. Whitfeld.

* Signifies an author already recorded in AustLit

\begin{tabular}{|l|l|l|}
\hline Author & Titles & $\begin{array}{l}\text { First } \\
\text { date }\end{array}$ \\
\hline
\end{tabular}




\begin{tabular}{|c|c|c|}
\hline Ahearn, Minnie & $\begin{array}{l}\text { "Nina's Mistake" } \\
\text { "Aileen's Troubles" }\end{array}$ & $\begin{array}{l}1896 \\
1898\end{array}$ \\
\hline * Atkins, R. A. & "Harry Linton's Dowfall: A Story of Old Sydney" & 1868 \\
\hline August, John & "A Commonplace Daughter" & 1893 \\
\hline $\begin{array}{l}\text { * Badham, Miss E. } \\
\text { A. }\end{array}$ & "Society, Friendship and Love" & 1886 \\
\hline Baker, Goodwin & "From Dark to Dawn: A Back Block Romance" & 1896 \\
\hline Bevan, Edward & $\begin{array}{l}\text { "Jenny. A Story of the North Queensland } \\
\text { Plantations" } \\
\text { "The Very Best Society: A Tale of Queensland Bush } \\
\text { Life" } \\
\text { "His Wretched Luck: A Story of the Discovery of a } \\
\text { Mine" } \\
\text { "The Recidivistes: A Story of French Convict Life" } \\
\text { "Bush Crossways From a Buckboard" } \\
\text { "Captain Jack: A Tale of Modern Buccaneering in } \\
\text { the South Pacific" }\end{array}$ & $\begin{array}{l}1885 \\
1886 \\
1887 \\
1888 \\
1891 \\
1891\end{array}$ \\
\hline Bowling, E. J. & $\begin{array}{l}\text { "Our Kangaroo Camp at Rothbury Mountains" } \\
\text { "Over Many Seas; or, Half Round the World" } \\
\text { "The McGuires of Ballypossum; Or, The Son of an } \\
\text { Informer" }\end{array}$ & $\begin{array}{l}1890 \\
1891 \\
1893\end{array}$ \\
\hline Brees, Harold & "Curlew; or, In Days Gone By" & 1894 \\
\hline Bruce, Elder & "A Theatrical Marriage" & 1896 \\
\hline $\begin{array}{l}\text { * Cameron, William } \\
\text { A. }\end{array}$ & "Keith Hope" & 1897 \\
\hline * Carroll, Janet & $\begin{array}{l}\text { "“"By the River's Side" } \\
\text { "Theodora Vale. A Story in Six Chapters" } \\
\text { "Harriette Hurst's Christmas" }\end{array}$ & $\begin{array}{l}1882 \\
1882 \\
1883\end{array}$ \\
\hline * Chads, Mrs & $\begin{array}{l}\text { "The Haunted Grange" } \\
\text { "Fulke Egerton's Vow" }\end{array}$ & $\begin{array}{l}1880 \\
1881\end{array}$ \\
\hline * Charles, E. & $\begin{array}{l}\text { "The Rightful Heir. An Australian Christmas Story" } \\
\text { "Under the Southern Cross: A Tale of Australian } \\
\text { Life" } \\
\text { "Guilty or Not? An Australian Tale" } \\
\text { "An Australian Idyl" } \\
\text { "Miss Ingram's Heiress" } \\
\text { "The Wilfulness of Winnie" }\end{array}$ & $\begin{array}{l}1884 \\
1884 \\
1885 \\
1887 \\
1889 \\
1897\end{array}$ \\
\hline $\begin{array}{l}* \text { Cleland, E. } \\
\text { Davenport }\end{array}$ & $\begin{array}{l}\text { "Clarissa's Lover" } \\
\text { "From Desk to Diggings, Or A Golden Christmas" } \\
\text { "Phantoms of the Past. A Bush Legend" } \\
\text { "The Curious Experience of Mr Brownlow Timmins" } \\
\text { "Dandy Dick's Diversion" } \\
\text { "Miss Nomer's Nonsense" } \\
\text { "The Coltbreaker's Courtship" } \\
\text { "Wininowie" }\end{array}$ & $\begin{array}{l}1886 \\
1887 \\
1887 \\
1887 \\
1888 \\
1888 \\
1888 \\
1888\end{array}$ \\
\hline * Clotilde & $\begin{array}{l}\text { "Mr Emerson's Client" } \\
\text { "Lost" } \\
\text { "Hazel" }\end{array}$ & $\begin{array}{l}1873 \\
1876 \\
1877\end{array}$ \\
\hline * Cohen, Philip & "A Terrible Christmas Day. A True Story of the & 1892 \\
\hline
\end{tabular}




\begin{tabular}{|c|c|c|}
\hline & $\begin{array}{l}\text { Olden Time" } \\
\text { "The First Nugget" }\end{array}$ & 1894 \\
\hline * Collins, William & $\begin{array}{l}\text { "Adventures of a Somnambulist: An Australian } \\
\text { Story" } \\
\text { "Agnes Meredith's Birthday Party", }\end{array}$ & $\begin{array}{r}1886 \\
1886 \\
\end{array}$ \\
\hline * Conant, H. A. & $\begin{array}{l}\text { "Carleton's Luck; Or, A Maid of Omeo: A Story of } \\
\text { the Mines" } \\
\text { "The Colt from Crooked Creek" }\end{array}$ & $\begin{array}{r}1896 \\
1897 \\
\end{array}$ \\
\hline $\begin{array}{l}\text { Congreve, Henry } \\
\text { John }\end{array}$ & $\begin{array}{l}\text { "For Dear Art's Sake. A Story of To-Day" } \\
\text { "Change and Mystery" } \\
\text { "Nulingee: An Australian Tale of Bush and } \\
\text { Diggings" } \\
\text { "Old Roach and His Adopted Daughter" } \\
\text { "Gordon Balterstone; Or, The Unfulfilled Prediction" } \\
\text { "Clarise; or, Which Is the Man" }\end{array}$ & $\begin{array}{l}1882 \\
1885 \\
1885 \\
1885 \\
1887 \\
1888\end{array}$ \\
\hline Corinda & $\begin{array}{l}\text { "Viola: A Tale from Shakespeare" } \\
\text { "Madeline" } \\
\text { "The Last } £ 20 \text { Note" } \\
\text { "John Marston’s Sacrifice" } \\
\text { "Murphy’s Man; Or, Between Two Lovers" }\end{array}$ & $\begin{array}{l}1885 \\
1890 \\
1890 \\
1891 \\
1892\end{array}$ \\
\hline * Crozier, James & $\begin{array}{l}\text { "Feminter; Or, The Aurora Land of the South" } \\
\text { "Solved by Time. A Story of the Eureka Stockade" }\end{array}$ & $\begin{array}{l}1895 \\
1895 \\
\end{array}$ \\
\hline * Doidge, Edwin & $\begin{array}{l}\text { "The Daughters of Eve. A Tale of the Maori War" } \\
\text { "Marian Gonisby" }\end{array}$ & $\begin{array}{l}1898 \\
1899\end{array}$ \\
\hline * Downes, Marion & "Monica. A Sea-Shore Idyll" & 1899 \\
\hline Echo & "Dingo Creek: A Christmas Tale of the Yarra Track" & 1887 \\
\hline Edith & "Olive Vanstone" & 1878 \\
\hline * Effra & $\begin{array}{l}\text { "Fortune My Foe. A Tale of the Old Land and the } \\
\text { New" }\end{array}$ & 1895 \\
\hline $\begin{array}{l}\text { * Egremont, } \\
\text { Godfrey }\end{array}$ & "The Kennises" & 1881 \\
\hline * Ellis, Edward & $\begin{array}{l}\text { "Mrs Holterby's Troubles: A Tale of the Day" } \\
\text { "Mrs Widgery's Lodgers" }\end{array}$ & $\begin{array}{l}1876 \\
1885 \\
\end{array}$ \\
\hline Eucalyptus & $\begin{array}{l}\text { "Neuroomia: A New Continent" } \\
\text { "Alice Laverne" }\end{array}$ & $\begin{array}{l}1892 \\
1893\end{array}$ \\
\hline * Eugah & $\begin{array}{l}\text { "A Real Good Fellow" } \\
\text { "A Very Sad Event in the History of Mr Jones" } \\
\text { "Viola Linn: An Australian Story" } \\
\text { "Whatsoever a Man Soweth" }\end{array}$ & $\begin{array}{l}1892 \\
1893 \\
1893 \\
1895\end{array}$ \\
\hline $\begin{array}{l}* \text { Evans, Henry } \\
\text { Congreve }\end{array}$ & "For Dear Art’s Sake. A Story of To-Day" & 1882 \\
\hline * Falk, David G. & $\begin{array}{l}\text { "Miss Roberts's Lovers: An Australian Story" } \\
\text { "Towser Bill's Troubles" } \\
\text { "Gabriel Lobo; or, The Legend of Trodd's Flat. A } \\
\text { Story of the Diggings" } \\
\text { "The Man from the Territory" } \\
\text { "A Silver King" } \\
\text { "The Land of Promise" } \\
\text { "The Harrow Bushrangers" }\end{array}$ & $\begin{array}{l}1883 \\
1883 \\
1886 \\
1886 \\
1889 \\
1890 \\
1891\end{array}$ \\
\hline
\end{tabular}




\begin{tabular}{|c|c|c|}
\hline & $\begin{array}{l}\text { "John Brede, Bushman: Three Chapters from His } \\
\text { Life" }\end{array}$ & 1899 \\
\hline Farley, Rice & $\begin{array}{l}\text { "Plot and Counterplot. In Two Parts" } \\
\text { "A Double Dealer" }\end{array}$ & $\begin{array}{l}1889 \\
1890\end{array}$ \\
\hline Fenton, Alberta L. & "Ruby" - l & 1886 \\
\hline $\begin{array}{l}* \text { Ferrar, William } \\
\text { Moore }\end{array}$ & "The Maxwells of Bremgarten" & 1867 \\
\hline $\begin{array}{l}\text { Goldney, Jessie } \\
\text { Maria }\end{array}$ & $\begin{array}{l}\text { "A Woman's Faith" } \\
\text { "Isabella Randell's Dream" } \\
\text { "Our Carrie" } \\
\text { "Like a Dream" } \\
\text { "Esther Vere's Petition" }\end{array}$ & $\begin{array}{l}1876 \\
1877 \\
1877 \\
1879 \\
1889 \\
\end{array}$ \\
\hline Goulter, Horace & "Bound by Love" & 1892 \\
\hline * Grassie, James & $\begin{array}{l}\text { "A Cruise in the Polar Sea" } \\
\text { "Narrative of the Loss of The Fame" } \\
\text { "John, the Bishop: A Tale of the Dark Days of } \\
\text { Tasmania" }\end{array}$ & $\begin{array}{l}1873 \\
1873 \\
1877\end{array}$ \\
\hline Gray, Captain East & "Fortune's Freaks: An Original Australian Story" & 1898 \\
\hline $\begin{array}{l}* \text { Growden, Oliver } \\
\text { H. }\end{array}$ & "A Man and His Destiny" & 1895 \\
\hline Hackney, Esther & "Thistledown" & 1899 \\
\hline Harris, Mrs Julia S. & $\begin{array}{l}\text { "From Shadow Land; or A Traveller Returned" } \\
\text { "Sir Jaspar's Ward, or The Wraith of Trevor Park" } \\
\text { "Euphemia Redmond: The Guardian Spirit of } \\
\text { Knockmey Hall" }\end{array}$ & $\begin{array}{l}1892 \\
1893 \\
1894\end{array}$ \\
\hline Hart, Frank H. & "Won by Jockeyship: A Sporting Sketch" & 1898 \\
\hline $\begin{array}{l}* \text { Haverfield, Robert } \\
\text { Ross }\end{array}$ & $\begin{array}{l}\text { "Scattered Leaves from Peregrine Pick's Diary: A } \\
\text { Romance of Old Bendigo" } \\
\text { "The Romance of the Rallaby Riders" }\end{array}$ & $\begin{array}{l}1889 \\
1889\end{array}$ \\
\hline $\begin{array}{l}\text { * Hawkes, Henry } \\
\text { Morgan }\end{array}$ & $\begin{array}{l}\text { "Musical Mysteries. A Bachelor's Adventures in } \\
\text { Search of a Happy Home" } \\
\text { "Vane Tresham. A Story of Metmepsychosis" } \\
\text { "In Sackcloth and Ashes" } \\
\text { "Three Sons of Anak" } \\
\text { "Beyond the Seas" } \\
\text { "An Australian Galatea. A Story of Exploration and } \\
\text { Strange Discovery" }\end{array}$ & $\begin{array}{l}1873 \\
1884 \\
1885 \\
1886 \\
1887 \\
1888\end{array}$ \\
\hline Heathfield, Alice & "For Ever and Aye. A Sydney Romance" & 1879 \\
\hline $\begin{array}{l}\text { Henty, Mrs } \\
\text { Richmond }\end{array}$ & "The Devil's Own. An Australian Story" & 1891 \\
\hline Hewitson, T. & "Remember" & 1887 \\
\hline Holden, Rev. E. W. & "John Brown and His Dog Faithful" & 1884 \\
\hline * Kibble, Robert & "Hector Mactavish; or, The Scotchman in Australia" & 1847 \\
\hline $\begin{array}{l}\text { Kitchen, William } \\
\text { Freeman }\end{array}$ & $\begin{array}{l}\text { "The Mountain Mystery. Or, The Stone of the Sacred } \\
\text { Death" }\end{array}$ & 1897 \\
\hline * Lane, William & $\begin{array}{l}\text { "As Others See Us. A Yankee Girl's Impressions of } \\
\text { the Sunny South" }\end{array}$ & 1885 \\
\hline $\begin{array}{l}\text { Langford, Ben. } \\
\text { Franklin }\end{array}$ & $\begin{array}{l}\text { "The Last of the Montezamas: A Tale of Life's } \\
\text { Sunshine and Death's Shadows" }\end{array}$ & 1883 \\
\hline
\end{tabular}




\begin{tabular}{|c|c|c|}
\hline & $\begin{array}{l}\text { "Madame Delamere: How I found Her, How I won } \\
\text { Her, and How I lost Her" }\end{array}$ & 1885 \\
\hline Laurie, Mrs D. F. & "A Christmas Pantomime" & 1893 \\
\hline * Liston, Ellie & "The Stauntons. A South Australian Story" & 1871 \\
\hline * Lockett, Jeannie & "Awfully Sudden Death" & 1887 \\
\hline MacAlister, Alister & "Adventures and Observations in Australia" & 1859 \\
\hline $\begin{array}{l}\text { * Mackenzie, Harold } \\
\text { M. }\end{array}$ & "The Verdict Was??? A Story of North Queensland" & 1891 \\
\hline * Martin, Catherine & $\begin{array}{l}\text { "Clare's Christmas Eve" } \\
\text { "How I Pawned My Opals" } \\
\text { "A Stray Kitten" } \\
\text { "Mrs Archibald Thorndale's Dog" } \\
\text { "Hansein's Disappearance: A Story of Saxon } \\
\text { Switzerland" [single issue] } \\
\text { "Teresa's Betrothal: A Tale of the Coral Fishery" }\end{array}$ & $\begin{array}{l}1881 \\
1881 \\
1883 \\
1890 \\
1897 \\
1898\end{array}$ \\
\hline $\begin{array}{l}* \text { McCrae, George } \\
\text { Gordon }\end{array}$ & "Nancy. A Story of the Fifties" & 1892 \\
\hline * McLean, Angus & "Arthur Landon, the Australian Bushman" & 1887 \\
\hline * Merrall, Edwin M. & "Matty and her Lovers: An Australian Story" & 1874 \\
\hline $\begin{array}{l}* \text { Mitchell, H. } \\
\text { Williams }\end{array}$ & "Love and Death" & 1877 \\
\hline Montcalm, Louis & "The Wealth of the West" & 1898 \\
\hline * Moore, J. S. & "The Bronze Chalice. An Australian Tale" & 1881 \\
\hline * Myers, Francis & $\begin{array}{l}\text { "A Wreath of Poppy Leaves" } \\
\text { "Sam Morrison's Experiences" }\end{array}$ & $\begin{array}{l}1890 \\
1891\end{array}$ \\
\hline * Newland, Simpson & "Dark Dunmore" & 1894 \\
\hline $\begin{array}{l}* \text { Nicholls, F. } \\
\text { Saunders }\end{array}$ & $\begin{array}{l}\text { "The Marvellous Island" } \\
\text { "The Five Comrades" }\end{array}$ & $\begin{array}{l}1888 \\
1889\end{array}$ \\
\hline $\begin{array}{l}\text { * Nicholson, John } \\
\text { H. }\end{array}$ & $\begin{array}{l}\text { "Dick. A Queensland Story" } \\
\text { "King Grumpy. A Story for Young People" } \\
\text { "Lampaspia" } \\
\text { "Yim Yonson" }\end{array}$ & $\begin{array}{l}1894 \\
1894 \\
1894 \\
1894\end{array}$ \\
\hline $\begin{array}{l}\text { Nottage, John } \\
\text { Silvester }\end{array}$ & $\begin{array}{l}\text { "Ruth Morven: A Christmas Story" } \\
\text { "Half a Century Ago" } \\
\text { "Paul Ferrel's Revenge: A Christmas Story" } \\
\text { "Singular Passage in the Life of the Late Robert } \\
\text { Warden, Solicitor" } \\
\text { "The Great Golconda Mine" } \\
\text { "Vidah" } \\
\text { "Dr Delmont" }\end{array}$ & $\begin{array}{l}1875 \\
1880 \\
1880 \\
1881 \\
1881 \\
1882 \\
1883\end{array}$ \\
\hline Nunn, Teddy & "The Life of a Jockey" & 1898 \\
\hline * O’Byrne, Joseph & $\begin{array}{l}\text { "Wooing in Arcadia" } \\
\text { "Under Southern Skies" }\end{array}$ & $\begin{array}{l}1885 \\
1892 \\
\end{array}$ \\
\hline * O’Sullivan, E. W. & $\begin{array}{l}\text { "Under the Southern Cross: A Romance Introducing } \\
\text { Stirring Scenes and Episodes in Australian History" }\end{array}$ & 1898 \\
\hline Olicana & $\begin{array}{l}\text { "Crowned with Good" } \\
\text { "The Love Story of a Senior Op" }\end{array}$ & $\begin{array}{l}1884 \\
1887\end{array}$ \\
\hline Osborne, Foster & "Cowabee" & 1882 \\
\hline
\end{tabular}




\begin{tabular}{|c|c|c|}
\hline & $\begin{array}{l}\text { "My Devil. A New Australian Story Full of } \\
\text { Sensational Incidents" }\end{array}$ & 1891 \\
\hline Paddy Melon & "An Episode in the Career of Billy Martin" & 1892 \\
\hline $\begin{array}{l}\text { Petersen, Elizabeth } \\
\text { Ida }\end{array}$ & "A Whited Sepulchre" & 1894 \\
\hline * Philpott, N. V. & $\begin{array}{l}\text { "Whom the Gods Love" } \\
\text { "Sisters Three" } \\
\text { "Under the Southern Cross" } \\
\text { "Morning Waits at the End of the World" }\end{array}$ & $\begin{array}{l}1893 \\
1894 \\
1894 \\
1897\end{array}$ \\
\hline * Poole, Cecil W. P. & "A Fatal Dream" & 1883 \\
\hline Puella & "Good at Last" & 1871 \\
\hline Quiz & "The Law's Decree: An Original Story" & 1878 \\
\hline Reynolds, Charles & "Mistaken Identity. A South Australian Novelette" & 1891 \\
\hline Roy, John & "Scotland Lang Syne" & 1875 \\
\hline Roy, Rich & "P. Q. R. S.: A Tale of the Melbourne G. P. O." & 1892 \\
\hline * Samson, E. A. & $\begin{array}{l}\text { "Ada and her Cousin Charles, A Tale for Victorian } \\
\text { Boys and Girls" } \\
\text { "The Patient Husband: A Tale for the Younger } \\
\text { Members of the Family" }\end{array}$ & $\begin{array}{l}1878 \\
1879\end{array}$ \\
\hline Shackell, Mrs & "Matched and Mated: A Romance in Real Life" & 1893 \\
\hline $\begin{array}{l}\text { * Sherard, Charles } \\
\text { Allan }\end{array}$ & $\begin{array}{l}\text { "In The Wake of Corunna: An Australian Racing } \\
\text { Story" }\end{array}$ & 1898 \\
\hline Sigma & "Amor Vincit" & 1875 \\
\hline Smith, Arthur Foster & "My Campaign in the Trans-Vaal" & 1880 \\
\hline Smyley, Luke & $\begin{array}{l}\text { "The Romeo Married; The Real Tragedy" } \\
\text { "The Three Programmes; Or, The Great Divorce } \\
\text { Case" } \\
\text { "The Kidnappers; or, The Father's Revenge" }\end{array}$ & $\begin{array}{l}1876 \\
1876 \\
1878 \\
\end{array}$ \\
\hline * Sparrow, Lionel & $\begin{array}{l}\text { "The Loss of the Black Swan: A Tale of Love and } \\
\text { Adventure" } \\
\text { "The Tragedy at Waritungah" }\end{array}$ & $\begin{array}{l}1895 \\
1895\end{array}$ \\
\hline * St Buxton, H. A. & "The Old Garden Seat" & 1881 \\
\hline $\begin{array}{l}\text { * Stephen, Harold } \\
\text { W. H. }\end{array}$ & $\begin{array}{l}\text { "Alma: An Original Australian Story" } \\
\text { "Ettie's Error; An Australian Story" } \\
\text { "The Bewitched King: An Episode in the History of } \\
\text { Bohemia" } \\
\text { "Goths, Huns, and Vandals: A Novel" } \\
\text { "In Quest of the Holy Grail" } \\
\text { "The New Editor: An Episode in the History of } \\
\text { Warrener's Gulch, California" }\end{array}$ & $\begin{array}{l}1876 \\
1883 \\
1886 \\
1887 \\
1887 \\
1889\end{array}$ \\
\hline Stocks, A. Mabel & "Studies in Bush Life. On a Gippsland Selection" & 1899 \\
\hline Stow, J. P. & "Voyage of the Forlorn Hope in $1865 "$ & 1894 \\
\hline $\begin{array}{l}\text { * Sutherland, } \\
\text { George }\end{array}$ & "Danbury's Agent. A Tale of London and Adelaide" & 1887 \\
\hline $\begin{array}{l}\text { Sweetapple, Anna } \\
\text { Mapleson }\end{array}$ & $\begin{array}{l}\text { "Sowing the Wind" } \\
\text { "Brought to Mind" } \\
\text { "How I Came to Australia" } \\
\text { "A Victim of Intrigue" }\end{array}$ & $\begin{array}{l}1884 \\
1887 \\
1890 \\
1899\end{array}$ \\
\hline Thorne, Ambrose & "The Pity of It. A Sydney Story" & 1896 \\
\hline
\end{tabular}




\begin{tabular}{|c|c|c|}
\hline * Tom Bluegum & $\begin{array}{l}\text { "The Stolen Bullock" } \\
\text { "Love is of God" } \\
\text { "The Kangaroo Flat Revival" } \\
\text { "The Middle Ridge Appointment" }\end{array}$ & $\begin{array}{l}1898 \\
1899 \\
1899 \\
1899\end{array}$ \\
\hline Twyford, Paul & $\begin{array}{l}\text { "Weedon's Folly; Or, The Big Find of Gold at } \\
\text { Lodore" } \\
\text { "Dutchy's Wife" }\end{array}$ & $\begin{array}{l}1891 \\
1898\end{array}$ \\
\hline Underwood, Captain & "Recollections of a Pioneer" & 1878 \\
\hline * Utting, J. J. & $\begin{array}{l}\text { "Blind Bella; or, A Ride for Life: A New Zealand } \\
\text { Story" } \\
\text { "The Golden Cross" } \\
\text { "Frank Calvary. A Semi-Nautical Novel" }\end{array}$ & $\begin{array}{l}1882 \\
1884 \\
1885\end{array}$ \\
\hline * Walch, Garnet & $\begin{array}{l}\text { "Larrikin Jack: A Story of a Woman's Devotion" } \\
\text { "Queer in the Head. A Story of an Old Man and a } \\
\text { Drum" }\end{array}$ & $\begin{array}{l}1886 \\
1886 \\
\end{array}$ \\
\hline * Waterhouse, J. M. & $\begin{array}{l}\text { "The Prince of Ariedam" } \\
\text { "On the Wrong Track" } \\
\text { "Pilgrims from the Seventh Pleiad" }\end{array}$ & $\begin{array}{l}1892 \\
1893 \\
1896\end{array}$ \\
\hline Watkins, W. & $\begin{array}{l}\text { "Found at Last" } \\
\text { "Proving an Alibi" } \\
\text { "Vernon Bascom: A Novel" }\end{array}$ & $\begin{array}{l}1877 \\
1877 \\
1879\end{array}$ \\
\hline West, Mark & $\begin{array}{l}\text { "Chronicles of Marah. Jim Worthington's } \\
\text { Experiment" } \\
\text { "Chronicles of Marah. Miss Nasmyth's Legacy and } \\
\text { What Came of It" } \\
\text { "Blame Shakespeare" } \\
\text { "Jane" }\end{array}$ & $\begin{array}{l}1883 \\
1884 \\
1889 \\
1899\end{array}$ \\
\hline $\begin{array}{l}* \text { Whitelocke, } \\
\text { Nelson P. }\end{array}$ & $\begin{array}{l}\text { "A Remittance Man" } \\
\text { "Maud's Troubles, A Love Story" } \\
\text { "The Pen and the Pistol. A Realistic Love Story" }\end{array}$ & $\begin{array}{l}1890 \\
1892 \\
1892 \\
\end{array}$ \\
\hline $\begin{array}{l}* \text { Whitfeld, Adeline } \\
\text { J. }\end{array}$ & $\begin{array}{l}\text { "Madge" } \\
\text { "Rex" } \\
\text { "Farmer Mack" } \\
\text { "Double Ugly" } \\
\text { "Uncle Turk" } \\
\text { "The Living Pen" } \\
\text { "On The Measureless Plain. A Colonial Story" }\end{array}$ & $\begin{array}{l}1892 \\
1894 \\
1895 \\
1896 \\
1896 \\
1897 \\
1898\end{array}$ \\
\hline $\begin{array}{l}\text { Wilkinson, George } \\
\text { Blakiston }\end{array}$ & "Yarns on Olden Times" & 1880 \\
\hline * Winstanley, Eliza & "The Flower of Botany Bay" & 1879 \\
\hline * Wren, Jenny & $\begin{array}{l}\text { "Missing. A Christmas Story" } \\
\text { "Sir Godfrey’s Decree" } \\
\text { "A Man and His Money" }\end{array}$ & $\begin{array}{l}1891 \\
1897 \\
1899 \\
\end{array}$ \\
\hline $\begin{array}{l}\text { Wright, James W. } \\
\text { ("Captain Lacie") }\end{array}$ & $\begin{array}{l}\text { "Barumba Station; Or, Amy River's Sacrifice. A } \\
\text { True and Eventful Narrative of the Early Days in } \\
\text { New South Wales" } \\
\text { "The Tamar Pirates. A Sensational and True } \\
\text { Narrative of Adventure of the Early Days in Van } \\
\text { Diemen's Land" } \\
\text { "Davies the Bushranger. An Australian Story" }\end{array}$ & 1895 \\
\hline
\end{tabular}


Wright, James W.

("Ivan Dexter")
"From Prison to Parliament. An Australian Novel" "The Mount Macedon Mystery"

"In the Wake of Fortune: An Australian Story"
1891

1891

1893 